\title{
Role of surface chemistry on electric double layer capacitance of carbon materials
}

\author{
M.J. Bleda-Martínez a , J.A. Maciá-Agulló a , D. Lozano-Castelló a , E. Morallón ${ }^{\mathrm{b}}$, \\ D. Cazorla-Amorós ${ }^{\mathrm{a}, *}$, A. Linares-Solano ${ }^{\mathrm{a}}$ \\ a Departamento de Química Inorgánica, Universidad de Alicante, Ap. 99, E-03080 Alicante, Spain \\ b Departamento de Química-Física, Universidad de Alicante, Ap. 99, E-03080 Alicante, Spain
}

Received 1 February 2005; accepted 16 May 2005

\begin{abstract}
A large number of porous carbon materials with different properties in terms of porosity, surface chemistry and electrical conductivity, were prepared and systematically studied as electric double layer capacitors in aqueous medium with $\mathrm{H}_{2} \mathrm{SO}_{4}$ as electrolyte. The precursors used are an anthracite, general purpose carbon fibres and high performance carbon fibres, which were activated by $\mathrm{KOH}, \mathrm{NaOH}, \mathrm{CO}_{2}$ and steam at different conditions. Among all of them, an activated anthracite with a BET surface area close to $1500 \mathrm{~m}^{2} / \mathrm{g}$, presents the best performance, reaching a value of $320 \mathrm{~F} / \mathrm{g}$, using a three-electrode system. The results obtained for all the samples, agree with the well-known relationship between capacitance and porosity, and show that the CO-type oxygen groups have a positive contribution to the capacitance. A very good correlation between the specific capacitance and this type of oxygen groups has been found.
\end{abstract}

(c) 2005 Elsevier Ltd. All rights reserved.

Keywords: Activated carbon; Temperature programmed desorption; Electrochemical properties; Electrical properties; Surface oxygen complexes

\section{Introduction}

The performance of porous carbons as electrical double layer capacitors (EDLC) is strongly dependent on a number of factors which include carbon material properties (such as porosity, surface chemistry and electrical conductivity), preparation method of the electrode and electrolyte characteristics (such as ions dimensions, dielectric constant, etc.) [1]. The proper selection of these properties will allow to optimize the EDLC.

Regarding porous carbons, it is known that double layer capacitance of carbon materials depends on the porosity, and some correlations with parameters such

\footnotetext{
* Corresponding author. Fax: +34 965903454.

E-mail address: cazorla@ua.es (D. Cazorla-Amorós).
}

as specific surface area or the micropore volume have already been published [2-5]. The higher the surface area of carbon materials, the higher is the capacitance value. However, important deviations from this trend have been demonstrated [2], confirming that there are other important factors that contribute to double layer capacitance. In addition, the role of pore size distribution has been discussed previously [2,3,6-9]. Activated carbons with large micropores are found to be more suitable for this application since the pores non-accessible to the electrolyte do not contribute to the total double layer capacitance. It must be noted that the optimum pore size will be dependent on the size of the electrolyte used.

Apart from porosity, surface chemistry might also be a relevant parameter [2,10-13]. Oxygen functionalities seem to enhance the capacitance value. However, 
different surface oxygen groups do not contribute in the same way $[11,13]$. It is proposed that these oxygen groups improve carbon wettability, although they can also contribute to capacitance by faradic reactions, inducing pseudocapacitance. Finally, the influence of electrical conductivity and structural order in the promotion of double layer capacitance has already been suggested [14-16].

In summary, the EDLC of a porous carbon depends on a complex combination of properties and, consequently, the selection of the proper precursor and preparation method will permit the improvement of the materials performance.

In this work, different precursors such as an anthracite, general purpose and high performance carbon fibres have been selected to prepare activated carbons. The activation was done by carbon gasification with $\mathrm{CO}_{2}$ and steam (i.e., the so-called physical activation) and by reaction with $\mathrm{KOH}$ and $\mathrm{NaOH}$ (i.e., the so-called chemical activation). As a result, we have obtained a large number of materials with different porosities, structure and surface chemistry, what is rarely found in the literature. These samples have been studied as EDLC in acidic aqueous medium $\left(\mathrm{H}_{2} \mathrm{SO}_{4} 1 \mathrm{M}\right)$. The materials have been deeply characterized in terms of porosity, surface chemistry and electrical conductivity, in order to deepen into their relevance to control the performance of carbon materials for EDLC application.

\section{Experimental}

\subsection{Activation process}

Chemical activation was done using $\mathrm{KOH}$ and $\mathrm{NaOH}$ as activating agents. Three different precursors were used: an anthracite (sample A), general purpose carbon fibres from an isotropic coal tar pitch (Donacarbo S-241, Osaka gas Co., Ltd.) (sample D) and high performance carbon fibres (PAN-based carbon fibres, Hexcel) (sample H). Anthracite based activated carbons were prepared using $\mathrm{KOH}$ activation. Details of the preparation process are available elsewhere [17]. General purpose and high performance carbon fibres were activated with both $\mathrm{KOH}$ and $\mathrm{NaOH}[18,19]$. The preparation conditions for each sample are included in Table 1.

Physical activation was carried out using $\mathrm{CO}_{2}$ and steam as activating agents. Two different precursors were used: Donacarbo and Kureha carbon fibres (samples $\mathrm{D}$ and $\mathrm{K}$, respectively). Donacarbo was activated with $\mathrm{CO}_{2}$ as described in a previous study [18] and Kureha fibres were activated with steam $[20,21]$. The preparation conditions for each sample are included in Table 2.

\subsection{Porous texture characterization}

Porous texture of all samples was determined by physical adsorption $\left(\mathrm{N}_{2}\right.$ at $77 \mathrm{~K}$ and $\mathrm{CO}_{2}$ at $273 \mathrm{~K}$ ) using an automatic adsorption system (Autosorb-6, Quantrachrome) after samples out-gassing at $523 \mathrm{~K}$ under vacuum for $4 \mathrm{~h}$. The total micropore volume (pore size smaller than $2 \mathrm{~nm}$ ) was calculated from the application of the Dubinin-Radushkevich equation to the $\mathrm{N}_{2}$ adsorption at $77 \mathrm{~K}$. The narrow micropore volume (pore size smaller than around $0.7 \mathrm{~nm}$ ) has been assessed from $\mathrm{CO}_{2}$ adsorption at $273 \mathrm{~K}$ using the DR equation [22-25]. The densities of the adsorbed phase used for the calculations, were 0.808 and $1.023 \mathrm{~g} / \mathrm{ml}$ for $\mathrm{N}_{2}$ and $\mathrm{CO}_{2}$, respectively. The specific surface area was calculated by the BET equation.

\subsection{Surface chemistry characterization}

Temperature programmed desorption (TPD) experiments were done in a DSC-TGA equipment (TA Instruments, SDT 2960 Simultaneous) coupled to a mass spectrometer (Thermostar, Balzers, GSD 300 T3), to characterize the surface chemistry of all samples. In these experiments, $10 \mathrm{mg}$ of the sample were heated up to $950{ }^{\circ} \mathrm{C}$ (heating rate $20^{\circ} \mathrm{C} / \mathrm{min}$ ) under a helium flow rate of $100 \mathrm{ml} / \mathrm{min}$.

\subsection{Electrical conductivity measurement}

Composite monoliths were prepared from selected samples in order to measure the electrical conductivity of the electrodes using a method described elsewhere [26]. These monoliths $(300 \mathrm{mg})$ were prepared from the porous carbon material and a cellulose-based binder (Saint Honoré) (90:10 wt.\%, respectively). Both materials were mixed and pressed up to 100 bars during half an hour. The composite pellet was pressed between two thin metallic sheets. Different potentials were applied and the current intensities were measured. The resistance of the pellet was determined from the slope of the voltage versus current plot.

\subsection{Double layer capacitance measurement}

To measure the electric double layer capacitance, composite electrodes were prepared from powder porous carbon material, acetylene black (Strem Chemicals) and binder (PVDC copolymer, aqueous dispersion (55\% solids), Sutcliffe Speakman), in a ratio 77:10:13 wt.\%, respectively. The materials were mixed and pressed up to 100 bars for $10 \mathrm{~min}$. The total electrode weight used for the measurements was about $70-90 \mathrm{mg}$. After that, the composite electrode was placed in a stainless steel mesh as a current collector. In order to measure the electric double capacitance of a single porous carbon elec- 
Table 1

Preparation conditions in chemical activation

\begin{tabular}{|c|c|c|c|c|c|}
\hline Sample & Activating agent & Activating agent/carbon ratio & Activation temperature $\left({ }^{\circ} \mathrm{C}\right)$ & Activation time $(\mathrm{h})$ & $\mathrm{N}_{2}$ flow rate $(\mathrm{ml} / \mathrm{min})$ \\
\hline $\mathrm{AK} 1$ & $\mathrm{KOH}$ & $1: 1$ & 700 & 1 & 800 \\
\hline $\mathrm{AK} 2$ & $\mathrm{KOH}$ & $2: 1$ & 650 & 1 & 800 \\
\hline $\mathrm{AK} 3$ & $\mathrm{KOH}$ & $3: 1$ & 750 & 1 & 800 \\
\hline DK1 & $\mathrm{KOH}$ & $0.5: 1$ & 750 & 1 & 500 \\
\hline DK2 & $\mathrm{KOH}$ & $2: 1$ & 750 & 1 & 500 \\
\hline DK3 & $\mathrm{KOH}$ & $4: 1$ & 750 & 1 & 500 \\
\hline DK4 & $\mathrm{KOH}$ & $6: 1$ & 750 & 1 & 500 \\
\hline DK5 & $\mathrm{KOH}$ & $8: 1$ & 750 & 1 & 500 \\
\hline DNal & $\mathrm{NaOH}$ & $0.5: 1$ & 750 & 1 & 500 \\
\hline $\mathrm{DNa} 2$ & $\mathrm{NaOH}$ & $2: 1$ & 750 & 1 & 500 \\
\hline $\mathrm{DNa} 3$ & $\mathrm{NaOH}$ & $4: 1$ & 750 & 1 & 500 \\
\hline $\mathrm{DNa} 4$ & $\mathrm{NaOH}$ & $6: 1$ & 750 & 1 & 500 \\
\hline DNa5 & $\mathrm{NaOH}$ & $8: 1$ & 750 & 1 & 500 \\
\hline HK1 & $\mathrm{KOH}$ & $4: 1$ & 750 & 0.27 & 500 \\
\hline HK2 & $\mathrm{KOH}$ & $5: 1$ & 750 & 1 & 500 \\
\hline HK3 & $\mathrm{KOH}$ & $8: 1$ & 750 & 1 & 500 \\
\hline HNal & $\mathrm{NaOH}$ & $4: 1$ & 750 & 0.27 & 500 \\
\hline $\mathrm{HNa} 2$ & $\mathrm{NaOH}$ & $5: 1$ & 750 & 1 & 500 \\
\hline $\mathrm{HNa} 3$ & $\mathrm{NaOH}$ & $8: 1$ & 750 & 1 & 500 \\
\hline
\end{tabular}

Table 2

Preparation conditions in physical activation

\begin{tabular}{lllcl}
\hline Sample & Activating agent & Activation temperature $\left({ }^{\circ} \mathrm{C}\right)$ & Activation time $(\mathrm{h})$ & Flow rate $(\mathrm{ml} / \mathrm{min})$ \\
\hline DC1 & $\mathrm{CO}_{2}$ & 890 & 3 & 500 \\
DC2 & $\mathrm{CO}_{2}$ & 890 & 9 & 500 \\
DC3 & $\mathrm{CO}_{2}$ & 890 & 22.5 & 500 \\
KS1 & $\mathrm{Steam}$ & 760 & 3.5 & $150\left(\mathrm{~N}_{2}\right) / 40(\mathrm{steam})$ \\
KS2 & Steam & 820 & 3 & $150\left(\mathrm{~N}_{2}\right) / 40(\mathrm{steam})$ \\
KS3 & Steam & 910 & 0.92 & $150\left(\mathrm{~N}_{2}\right) / 40(\mathrm{steam})$ \\
\hline
\end{tabular}

trode, the standard three-electrode cell configuration was employed. Reversible hydrogen electrode (RHE) was used as reference and a platinum wire was employed as a counter electrode. $\mathrm{H}_{2} \mathrm{SO}_{4}(1 \mathrm{M})$ was used as aqueous electrolyte. The capacitance value was measured by the galvanostatic method (at $2 \mathrm{~mA}$ ). The values have been calculated from the interval of voltage between 0.2 and $0.6 \mathrm{~V}$, as follows. The value of imposed current is divided by the slope of the lineal chronopotentiogram plot, taking the average value between charge and discharge process. The result is then divided by the weight of porous carbon that is about $77 \%$ of the total composite.

\section{Results and discussion}

\subsection{Porous texture characterization}

It is remarkable that 25 porous carbons from different precursors and preparation methods are gathered in this study, what offers a variety of porous texture and structure which is rarely found in the literature.
All the materials prepared have type I isotherms, what is characteristic of microporous solids. Table 3 contains the BET surface areas and the micropore volumes calculated from $\mathrm{N}_{2}$ adsorption data at $77 \mathrm{~K}\left[V_{\mathrm{DR}}\left(\mathrm{N}_{2}\right)\right]$ and $\mathrm{CO}_{2}$ adsorption data at $273 \mathrm{~K}\left[V_{\mathrm{DR}}\left(\mathrm{CO}_{2}\right)\right]$ for each sample. It is interesting to note that samples with different adsorption capacity and micropore size distributions have been developed. A more detailed description of the porous texture for each series of materials is included below, which is in agreement with previous results [1721].

In chemical activation, as a general trend, the adsorption capacity and, consequently, the porosity development, increase with increasing the hydroxide/carbon ratio. Additionally, the knee of the isotherms widens with the increase of the hydroxide/carbon ratio, thus indicating an increase of the micropore size distribution. The differences between $\mathrm{KOH}$ and $\mathrm{NaOH}$ activations have been shown to be dependent on the structure of the precursor as it has been previously reported $[18,19,27]$.

The comparison between the total micropore volume, $V_{\mathrm{DR}}\left(\mathrm{N}_{2}\right)$, and the narrow micropore volume, 
Table 3

Porous texture, quantification of oxygen surface groups obtained by TPD and capacitance values for all samples

\begin{tabular}{|c|c|c|c|c|c|c|}
\hline Sample & $S_{\text {BET }}\left(\mathrm{m}^{2} / \mathrm{g}\right)$ & $V_{\mathrm{DR}}\left(\mathrm{N}_{2}\right)\left(\mathrm{cm}^{3} / \mathrm{g}\right)$ & $V_{\mathrm{DR}}\left(\mathrm{CO}_{2}\right)\left(\mathrm{cm}^{3} / \mathrm{g}\right)$ & $\mathrm{CO}(\mu \mathrm{mol} / \mathrm{g})$ & $\mathrm{CO}_{2}(\mu \mathrm{mol} / \mathrm{g})$ & Capacitance $(\mathrm{F} / \mathrm{g})$ \\
\hline AK1 & 814 & 0.37 & 0.38 & 1957 & 570 & 184 \\
\hline $\mathrm{AK} 2$ & 1538 & 0.71 & 0.61 & 3415 & 768 & 321 \\
\hline AK3 & 2602 & 1.24 & 0.80 & 2221 & 557 & 250 \\
\hline DK1 & 351 & 0.16 & 0.22 & 1481 & 368 & 137 \\
\hline DK2 & 1092 & 0.49 & 0.46 & 2251 & 852 & 197 \\
\hline DK3 & 1637 & 0.75 & 0.63 & 1570 & 586 & 210 \\
\hline DK4 & 2229 & 0.91 & 0.69 & 1738 & 539 & 232 \\
\hline DK5 & 2424 & 0.96 & 0.71 & 1398 & 340 & 210 \\
\hline DNa1 & 173 & 0.08 & 0.18 & 1139 & 626 & 96 \\
\hline $\mathrm{DNa} 2$ & 1131 & 0.51 & 0.48 & 1439 & 466 & 164 \\
\hline $\mathrm{DNa} 3$ & 1758 & 0.80 & 0.56 & 1138 & 394 & 178 \\
\hline $\mathrm{DNa} 4$ & 2533 & 1.00 & 0.66 & 919 & 352 & 194 \\
\hline DNa5 & 3038 & 1.01 & 0.65 & 978 & 458 & 207 \\
\hline HK1 & 589 & 0.28 & 0.23 & 1198 & 599 & 136 \\
\hline HK2 & 878 & 0.41 & 0.29 & 1438 & 463 & 163 \\
\hline HK3 & 1243 & 0.60 & 0.39 & 1265 & 303 & 146 \\
\hline HNal & 346 & 0.16 & 0.13 & 609 & 587 & 91 \\
\hline $\mathrm{HNa} 2$ & 675 & 0.30 & 0.27 & 907 & 303 & 118 \\
\hline $\mathrm{HNa} 3$ & 872 & 0.40 & 0.30 & 1001 & 173 & 103 \\
\hline $\mathrm{DCl}$ & 645 & 0.29 & 0.30 & 1321 & 683 & 118 \\
\hline $\mathrm{DC} 2$ & 1502 & 0.69 & 0.50 & 1135 & 674 & 148 \\
\hline $\mathrm{DC} 3$ & 2442 & 1.15 & 0.42 & 678 & 308 & 146 \\
\hline KS1 & 493 & 0.22 & 0.24 & 929 & 295 & 131 \\
\hline KS2 & 1191 & 0.53 & 0.48 & 770 & 286 & 148 \\
\hline KS3 & 1546 & 0.68 & 0.42 & 851 & 279 & 147 \\
\hline
\end{tabular}

$V_{\mathrm{DR}}\left(\mathrm{CO}_{2}\right)$, gives information of the micropore size distribution [22-25]. Micropores smaller than $0.7 \mathrm{~nm}$ in size are measured by $V_{\mathrm{DR}}\left(\mathrm{CO}_{2}\right)$, and those smaller than $2 \mathrm{~nm}$ and bigger than $0.7 \mathrm{~nm}$ are calculated by the difference between $V_{\mathrm{DR}}\left(\mathrm{N}_{2}\right)$ and $V_{\mathrm{DR}}\left(\mathrm{CO}_{2}\right)$. In activated samples from anthracite and Donacarbo, low hydroxide/ carbon ratios give $V_{\mathrm{DR}}\left(\mathrm{CO}_{2}\right)>V_{\mathrm{DR}}\left(\mathrm{N}_{2}\right)$ which indicates that very narrow microporosity has been developed. As this ratio increases, the mean pore size is higher. Moreover, it is important to note that Donacarbo samples activated with $\mathrm{NaOH}$ develop wider microporosity than those activated with $\mathrm{KOH}$. For Hexcel activated samples, the micropore size distribution is wider in all the cases compared to the other precursors (i.e., anthracite and Donacarbo).

Activated carbon fibres prepared by physical activation with $\mathrm{CO}_{2}$ (Donacarbo samples) and with steam (Kureha samples), are essentially microporous. The micropore size distribution is narrow at low burnoffs and becomes wider with increasing the burnoff. Another remarkable finding is that the micropore size distributions obtained by physical activation are wider than by chemical activation with $\mathrm{KOH}$ or $\mathrm{NaOH}$.

In summary, a large number of porous carbons (powder and fibres) were prepared in our laboratory from different precursors and using four activating agents at different experimental conditions, which cover a wide range of porosities and surface areas (from 200 to $3000 \mathrm{~m}^{2} / \mathrm{g}$ ).

\subsection{Surface chemistry characterization}

Surface oxygen groups on carbon materials decompose upon heating producing $\mathrm{CO}$ and $\mathrm{CO}_{2}$ at different temperatures. It is known that $\mathrm{CO}_{2}$ evolves at low temperatures as a consequence of the decomposition of the acidic groups such as carboxylic groups or lactones $[28,29]$. The evolution of $\mathrm{CO}$ occurs at higher temperatures and is originated by decomposition of basic or neutral groups such as phenols, ethers and carbonyls $[28,29]$.

All activated carbon samples were characterized by TPD experiments. Table 3 contains the quantification of the amount of $\mathrm{CO}$ and $\mathrm{CO}_{2}$ desorbed in these experiments. The results of the TPD indicate that samples with a wide range of surface oxygen groups are available being, in all the cases, the $\mathrm{CO}$ evolved larger than the $\mathrm{CO}_{2}$. It must be noted that samples with oxygen contents from 1000 to $5000 \mu \mathrm{mol} / \mathrm{g}$ but similar surface areas, are available in this study, what is very useful to analyse the effect of the surface chemistry. Moreover, chemically activated samples with $\mathrm{KOH}$ have a higher oxygen content than the $\mathrm{NaOH}$ or the physically activated ones for a given raw material. Fig. 1 shows the oxygen content (i.e., $2 \mathrm{CO}_{2}+\mathrm{CO}$ ) for each sample versus the BET surface area. The figure includes lines, added to show the trends observed, which are not the fittings to the experimental results. 


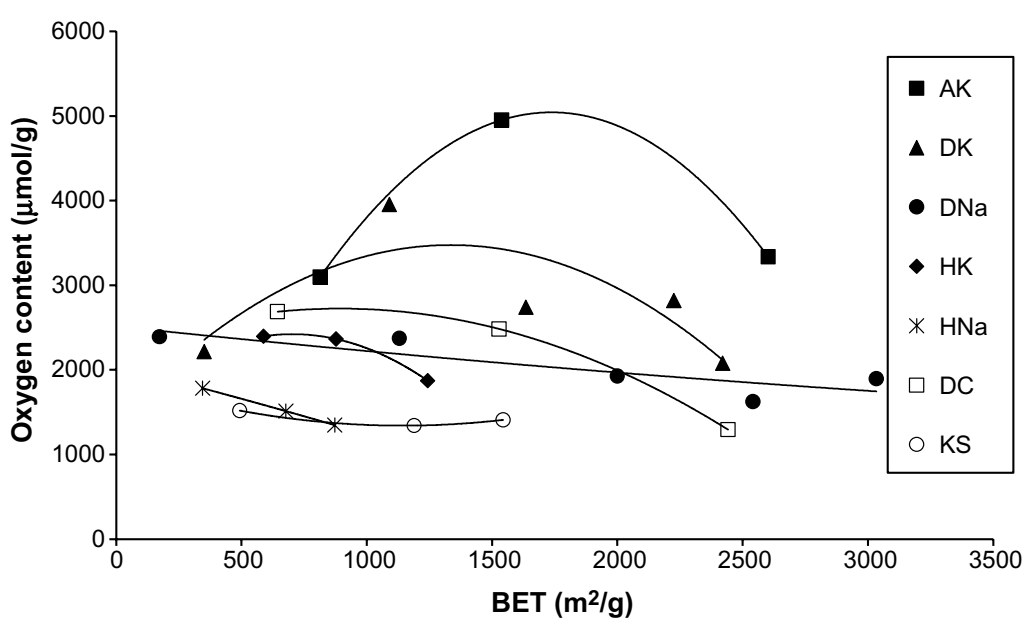

Fig. 1. Oxygen content versus BET surface area for all samples.

As a general trend, we observe that either the oxygen content goes through a maximum at moderate activations or decreases with the degree of activation.

\subsection{Electrical conductivity}

The electrical conductivity of the raw materials and selected porous carbons was measured (at least one activated sample corresponding to each precursor was measured). Table 4 shows the obtained values, including the nomenclature of the activated samples measured. It is important to mention that the shown value corresponds to the composites prepared as described in Section 2; then, all of them have the same composition, what makes easier the comparison.

From the table we can conclude that the activation carried out with the anthracite and the Donacarbo fibres increases the electrical conductivity, but it decreases for Hexcel precursor. The porous carbons having the highest conductivity are those prepared by physical activation using Kureha carbon fibres as precursor. The increase in electrical conductivity upon activation can be understood if we consider that the activation will remove the most disorganized parts of the precursor (i.e., the most reactive carbons), specially considering that the electrical conductivity of the raw material is not very

Table 4

Electrical conductivity measurements

\begin{tabular}{lll}
\hline Raw material & $\begin{array}{l}\text { Electrical } \\
\text { conductivity } \\
\text { (precursors) }(\mathrm{S} / \mathrm{m})\end{array}$ & $\begin{array}{l}\text { Electrical conductivity } \\
\text { (activated samples) } \\
(\mathrm{S} / \mathrm{m})^{\mathrm{a}}\end{array}$ \\
\hline Anthracite & $1.36 \times 10^{-7}$ & $8(\mathrm{AK} 1, \mathrm{AK} 3)$ \\
Donac & 4 & $6(\mathrm{DK} 5, \mathrm{DNa} 2, \mathrm{DC} 3)$ \\
Kureha & 12 & $26(\mathrm{KS} 1)$ \\
Hexcel & 39 & $19(\mathrm{HK} 3, \mathrm{HNa} 3)$ \\
\hline
\end{tabular}

${ }^{a}$ The values correspond to the average of the samples included between brackets. high. In the case of Hexcel fibres, which are high performance carbon fibres with a high degree of crystallinity, the activation will destroy part of this structural order thus decreasing the electrical conductivity. It must be noted that Hexcel carbon fibres cannot be activated by physical activation and that an aggressive chemical activation process is necessary to reach moderate porosity developments [19]. As previously observed [20,30], steam activation focuses in the outer parts of the fibres; so the porosity is created in the most external parts of the material compared to other activating agents, thus preserving the fibre structure in the inner regions, what can be beneficial to keep the electrical conductivity of the raw material.

\subsection{Electrical double layer capacitance: influence of porosity and oxygen content}

Table 3 contains the specific double layer capacitance of the samples measured for a current intensity of $2 \mathrm{~mA}$ (this corresponds to a current density of about $30 \mathrm{~mA} /$ g). It can be observed that high capacitance values are obtained for some samples. Among them, the activated anthracite presents the best performance, reaching a value of $321 \mathrm{~F} / \mathrm{g}$. This value is similar to one of the best found in the literature for activated carbons with BET surface areas close to $3000 \mathrm{~m}^{2} / \mathrm{g}$ [31]. It must be noted that the sample with the highest capacitance has a BET surface area of only about $1500 \mathrm{~m}^{2} / \mathrm{g}$ (i.e., sample AK2). This means that some additional factors apart from the surface area are contributing to the enhanced capacitance.

Fig. 2 shows the relationship between the BET surface area and the electric double capacitance for all samples. It can be seen that the capacitance values for the activated carbons fibres follow a linear relationship with BET surface area, except for the anthracite and Hexcel derived activated carbons, and for the samples with 


\section{ARTICLE IN PRESS}

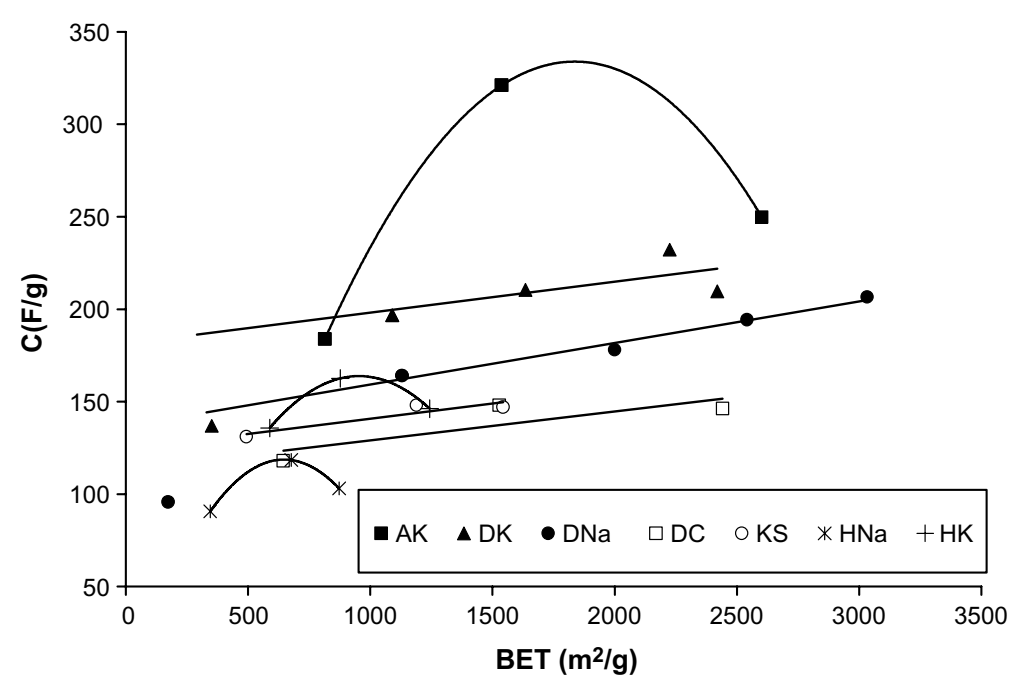

Fig. 2. Capacitance versus BET surface area for all samples.

the lowest surface areas, what is related with an ion sieving effect due to the small pore size of these materials $[2,8]$. In the case of the anthracite and Hexcel-derived activated carbons, the capacitance goes through a maximum, which is especially remarkable for sample AK2 (i.e., the sample with the largest capacitance). It should be emphasized that in this last sample, the porosity is sufficiently well developed to remove the ion-sieving effect mentioned before. Consequently, these deviations confirm that although porosity is a key parameter in this process, there are other factors which influence in a considerable extent the EDLC.

To analyse the influence of the surface chemistry on the capacitance values, we have calculated the specific capacitance (i.e., capacitance divided by BET surface area) and we have tried to correlate this parameter with the surface chemistry data collected in Table 3 . We have observed that the specific capacitance has not a good correlation neither with the number of oxygen groups desorbing as $\mathrm{CO}_{2}$ nor with the total oxygen content calculated as $2 \mathrm{CO}_{2}+\mathrm{CO}$, both referred to the surface area to account for this parameter. However, the best correlation is obtained when the plot is done versus the amount of surface oxygen groups desorbing as $\mathrm{CO}$ (Fig. 3). We find that the correlation is excellent for all the samples except for those prepared from Kureha and, specially, from Hexcel, which exhibit a deviation upwards with respect to the general trend. This conclusion, deduced for a large number of samples, prepared from different raw materials and using different preparation methods, confirm that the CO-type groups have a positive contribution to the capacitance of the porous

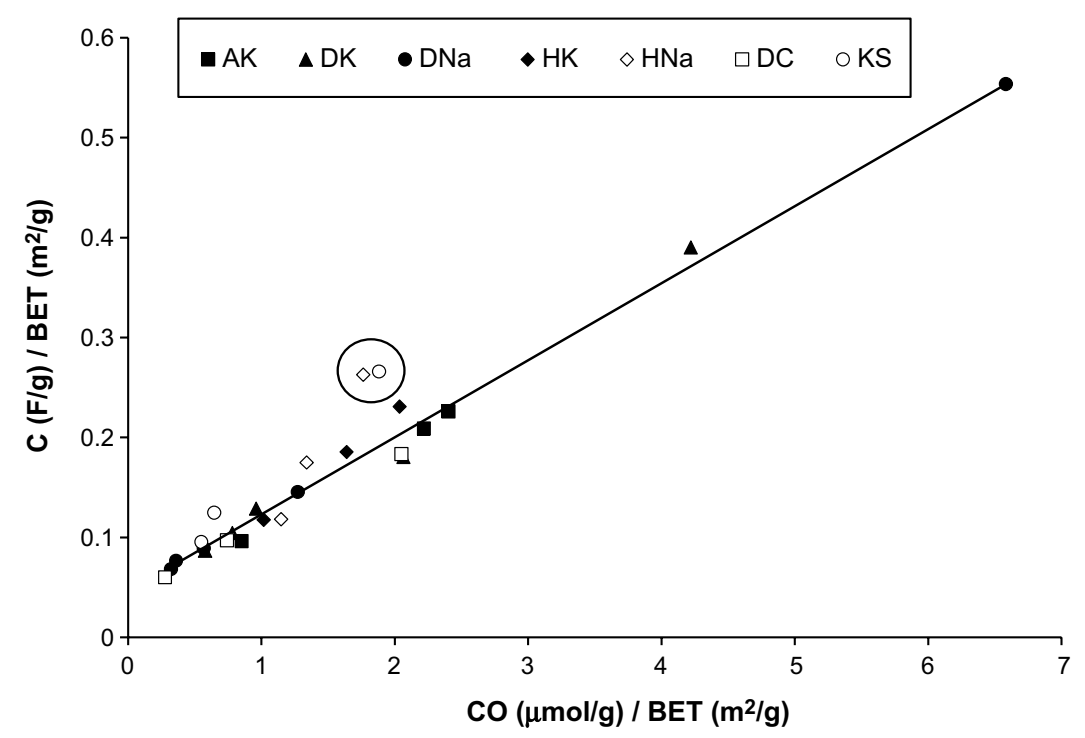

Fig. 3. Capacitance divided by BET surface area versus CO content divided by BET surface area. 
carbons. This result has been previously proposed from studies done with a given porous carbon after a selective modification of the surface chemistry $[10,13]$. In one of these papers [13], the authors conclude that the quinone-type oxygen groups are those having the better correlation with the capacitance. These conclusions may also explain the huge capacitance of exfoliated carbon fibres, prepared by $\mathrm{HNO}_{3}$, which composition nearly corresponds to graphite oxide [15].

The reason why the oxygen groups have a positive contribution to the capacitance can either be due to the improved wetability of the carbon material by the electrolyte, specially for aqueous solution, thus favouring the ions to reach the microporosity, or to a faradic process involving the oxygen groups that contribute to a pseudocapacitance. It is proposed [31] that the oxygen functionalities are detrimental for this application because the voltages applied for the charge and discharge may change the surface oxygen groups producing a loss in the capacitance. However, considering that the $\mathrm{CO}_{2-}$ type groups, which are the most unstable, are not favourable to increase the total capacitance of the materials and that the CO-type groups, which can have high stability, are beneficial, it might be possible to tailor the surface chemistry to have an enhanced and stable capacitance. The stability of the materials with a given surface chemistry and the development of the most appropriate functionalities will be analysed in the future.

The deviations found in Fig. 3 for two Hexcel and Kureha activated carbon samples marked in the figure could be explained considering that these are the porous materials having the higher electrical conductivity (see Table 4). This could indicate that electrical conductivity is another important parameter in double layer capacitors performance and that, for a given porosity, the more conductive the material is, the higher the capacitance value reached [14-16].

\section{Conclusions}

A large number of porous carbon materials have been prepared, from different precursors and using different preparation methods, covering a wide range of porosities, surface chemistry and electrical conductivity. The capacitance of the samples has been measured in aqueous solution. Among all of them, an activated anthracite with a BET surface area close to $1500 \mathrm{~m}^{2} / \mathrm{g}$, presents the best performance, reaching a value of $320 \mathrm{~F} / \mathrm{g}$. This value is very high and close to those published for activated carbons with surface areas close to $3000 \mathrm{~m}^{2} / \mathrm{g}$. The results obtained for all the samples, agree with the well-known relationship between capacitance and porosity, and show that the CO-type oxygen groups have a positive contribution to the capacitance. A very good correlation between the specific capacitance and this type of oxygen groups has been found. Additionally, the measurements suggest the favourable contribution of the electrical conductivity of the carbon material on the capacitance. The results indicate that an appropriate selection of the surface chemistry, with highly stable oxygen groups, and an increase of the electrical conductivity of the material, may be interesting possibilities to prepare improved materials for EDLC.

\section{Acknowledgment}

The authors thank MEC for financial support (Project PPQ2003-03884). M.J.B.-M. and J.A.M.-A. thank University of Alicante for the thesis grant.

\section{References}

[1] Conway BE. Electrochemical capacitors. New York: Kluwer Academic/Plenum Publishers; 1999.

[2] Lozano-Castelló D, Cazorla-Amorós D, Linares Solano A, Shiraishi S, Kurihara H, Oya A. Influence of pore structure and surface chemistry on electric double layer capacitance in nonaqueous electrolyte. Carbon 2003;41:1765-75.

[3] Shiraishi S, Kurihara H, Oya A. Electric double layer capacitance of mesoporous activated carbon fiber. Electrochemistry 2001; 69(6):440-3.

[4] Yoon S, Lim S, Song Y, Ota Y, Qiao W, Tanaka A, et al. KOH activation of carbon nanofibers. Carbon 2004;42:1723-9.

[5] Teng H, Chang Y, Hsieh C. Performance of electric double-layer capacitors using carbons prepared from phenol-formaldehyde resins by KOH etching. Carbon 2001;39:1981-7.

[6] Shi H. Activated carbons and double layer capacitance. Electrochim Acta 1996;41(10):1633-9.

[7] Qu D, Shi H. Studies of activated carbons used in double layer capacitors. J Power Sources 1998;74:99-107.

[8] Gryglewicz G, Machnikowski J, Lorenc-Grabowska E, Lota G, Frackowiak E. Effect of pore size distribution of coal-based activated carbons on double layer capacitance. Electrochim Acta 2005;50:1197-206.

[9] Toupin M, Belanger D, Hill I, Quinn D. Performance of experimental carbon blacks in aqueous supercapacitors. J Power Sources 2005;140:203-10.

[10] Hsieh C, Teng H. Influence of oxygen treatment on electric double-layer capacitance of activated carbon fabrics. Carbon 2002;40:667-74.

[11] Nian Y, Teng H. Influence of surface oxides on the impedance behaviour of carbon-based electrochemical capacitors. J Electroanal Chem 2003;540:119-27.

[12] $\mathrm{Hu} \mathrm{C}$, Wang C. Effects of electrolytes and electrochemical pretreatments on the capacitive characteristics of activated carbon fabrics for supercapacitors. J Power Sources 2004;125:299-308.

[13] Okajima K, Ohta K, Sudoh M. Capacitance behaviour of activated carbon fibers with oxygen-plasma treatment. Electrochim Acta 2005;50(11):2227-31.

[14] Yang H, Yoshio M, Isono K, Kuramoto R. Improvement of commercial activated carbon and its application in electric double layer capacitors. Electrochem Solid State Lett 2002;5(6):A141-4.

[15] Toyoda M, Tani Y, Soneda Y. Exfoliated carbon fibers as an electrode for electric double layer capacitors in a $1 \mathrm{~mol} / \mathrm{dm}^{3}$ $\mathrm{H}_{2} \mathrm{SO}_{4}$ electrolyte. Carbon 2004;42:2833-7.

[16] Kim Y, Horie Y, Matsuzawa Y, Ozaki S, Endo M, Dresselhaus M. Structural features necessary to obtain a high specific 


\section{ARTICLE IN PRESS}

capacitance in electric double capacitors. Carbon 2004;42: 2423-32.

[17] Lozano-Castelló D, Lillo-Ródenas MA, Cazorla-Amorós D, Linares-Solano A. Preparation of activated carbons from Spanish anthracite, I. Activation by KOH. Carbon 2001;39(5):741-9.

[18] Maciá-Agulló JA, Moore BC, Cazorla-Amorós D, LinaresSolano A. Activation of coal tar pitch carbon fibres: physical activation vs chemical activation. Carbon 2004;42:1367-70.

[19] Maciá-Agulló JA, Moore BC, Cazorla-Amorós D, LinaresSolano A. Chemical activation by $\mathrm{KOH}$ and $\mathrm{NaOH}$ of carbon materials with different crystallinity. In: Extended abstracts, Carbon Conference, Oviedo, Spain. 2003. p. 197.

[20] Alcañiz-Monge J, Cazorla-Amorós D, Linares-Solano A, Yoshida S, Oya A. Effect of the activating gas on tensile strength and pore structure of pitch-based carbon fibres. Carbon 1994;32(7): 1277-83.

[21] Lillo-Ródenas MA. Retención de compuestos orgánicos volátiles a bajas concentraciones en carbón activado, $\mathrm{PhD}$ thesis, Universidad de Alicante, Alicante, Spain, 2004.

[22] Rodríguez-Reinoso F, Linares-Solano A. Microporous structure of activated carbons as revealed by adsorption methods. Chem Phys Carbon 1988;21:1-146.

[23] Cazorla-Amoros D, Alcaniz-Monge J, Linares-Solano A. Characterization of activated carbon fibers by $\mathrm{CO}_{2}$ adsorption. Langmuir 1996;12(11):2820-4.

[24] Cazorla-Amoros D, Alcaniz-Monge J, De la Casa Lillo MA, Linares-Solano A. $\mathrm{CO}_{2}$ as an adsorptive to characterize carbon molecular sieves and activated carbons. Langmuir 1998;14(16): 4589-96.

[25] Linares-Solano A, Salinas-Martínez de Lecea C, Alcaniz-Monge $\mathrm{J}$, Cazorla-Amoros D. Further advances in the characterization of microporous carbons by physical adsorption of gases. Tanso 1998;185:316-25.

[26] Montilla F, Morallon E, Vazquez JL, Alcaniz-Monge J, CazorlaAmoros D, Linares-Solano A. Carbon-ceramic composites from coal tar pitch and clays: application as electrocatalyst support. Carbon 2002;40(12):2193-200.

[27] Lillo-Rodenas MA, Juan-Juan J, Cazorla-Amoros D, LinaresSolano A. About reactions occurring during chemical activation with hydroxides. Carbon 2004;42(7):1371-5.

[28] Román MC, Cazorla-Amoros D, Linares-Solano A, SalinasMartínez de Lecea C. TPD and TPR characterization of carbonaceous supports and Pt/C catalysts. Carbon 1993;31: 895-902.

[29] Figueiredo JL, Pereira MFR, Freitas MMA, Órfao JJM. Modification of the surface chemistry of activated carbons. Carbon 1999;37:1379-89.

[30] Lozano-Castelló D, Raymundo-Piñero E, Cazorla-Amorós D, Linares Solano A, Müller M, Riekel C. Characterization of pore distribution in activated carbon fibers by microbeam small angle X-ray scattering. Carbon 2004;40:2727-35.

[31] Kierzek K, Frackowiak E, Lota G, Gryglewicz G, Machnikowski J. Electrochemical capacitors based on highly carbons prepared by $\mathrm{KOH}$ activation. Electrochim Acta 2004;49:515-23. 